\section{Relaco: a product to reduce water shoot formation around pruning wounds in pome fruit trees}

\author{
Csiszár L. ${ }^{1}$, Újvári M. ${ }^{2}$ and Panea, T. ${ }^{2}$ \\ ${ }^{I}$ Research and Extension Centre for Fruitgrowing \\ Vadastag 2., 4244 Úffehértó, Hungary \\ ${ }^{2}$ Scientific Academy of Agriculture and Forestry, \\ 'BIOS' Research and Production Centre \\ Fântânele 30, 3400 Cluj-Napoca, Romania
}

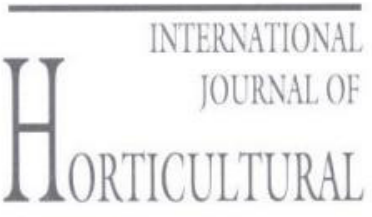
SCIENCE

AGROINFORM

Publishing House, Hungary

Key words: pruning wounds, water shoot formation, naphtalene-acetic acid

Summary: Larger cuts made during the winter pruning of pome fruit orchards a number of serious problems: the wounds serve as entrances for several branch-infecting pathogens, the numerous water shoots formed around the cut edges consume assimilates, shade the developing fruits, make the canopy dense, reduce the effectiveness of the pest management and cause extra work during next seasons pruning work. These problems can be eliminated by using proper wound protectants, like Relaco, a new Romanian wound protectant to cover larger pruning cuts of apple, pear and quince trees.

The treaments by Relaco resulted in a significant decrease in both the number and total length of water shoots formed around the cut egdes.

Abbreviations: naphtalene-acetic acid - NAA

\section{Introduction}

The severe winter pruning, or even renewal pruning of mature apple orchards always involves creating large pruning wounds. These wounds serve as entrances for several branchinfecting pathogens and insects. Due to the dieback of the infected branches these pathogens can cause significant losses of the cropping capacity of the canopy, and in the worst cases the infection can result in the loss of whole trees. The most important branch-infecting pathogens are: Phomopsis mali, Sphaeropsis malorum, and even Erwinia amylovora (Rozsnyai, 2001). Under wet conditions the fungi Chondrostereum purpureum (silver leaf) and Nectria galligena (canker) can cause significant infection (Williams, 1987).

However, most of the Hungarian apple growers don't incorporate the using of wound protectants in their orchard management program, although there are several products on the market as effective agents if applied right after pruning. This group of protectants include the following registered products in Hungary: Betica, Biocera, Fabalzsam, Fadoktor, Fagél, Florasca, Vulneron and Vulneron CS. Two products contain fungicides for better protection: Fixpol (copper+ benomil) and Faplaszt (8-hidroxi-kinolin+ bronopol).

Another consequence of the larger pruning wounds is the formation of water shoots around the edge of the cuts. These undesirable, worthless, vigorous shoots consume assimilates, shade the developing fruits, make the canopy dense, reduce the effectiveness of the plant protection and cause extra work during next seasons pruning work. To eliminate the formation of water shoots, some wound protectants include NAA. As for Hungary there are two registered products containing NAA: Betica and Vulneron.

\section{Material and method}

The new wound protectant Relaco is produced by the 'BIOS' Research and Production Centre of the Scientific Academy of Agriculture and Forestry (Cluj-Napoca, Romania). It is a registered product in Romania (registration number: Ministry of Health $\mathrm{Nr} 21 / 888$ ).

The treatments were carried out in the year of 2000 , based upon promising expereinces concerning treatments had been done the year before.

\section{Trial site 1: apple orchard}

Young trees of the English cider apple cultivar "Yarlington Mill" (on rootstock MM.106, planted in spring of 1997, spacing 5 by $3 \mathrm{~m}$ ) were pruned in the spring/summer of 2000. We had to make several large cuts on the trees due to a severe fireblight infection. Later on, the pruning cuts were treated with Relaco on the $15^{\text {th }}$ of June, 2000. Cut edges of the bark around the wounds (with a 
diameter larger than $1 \mathrm{~cm}$ ) have also been coated thoroughly. Number of treated wounds: 60 .

\section{Trial site 2: pear genebank}

Mature trees of several old pear varieties (on seedling pear rootstock, spacing 8 by 3 meters) were treated with Relaco, at the same time and the same way. Number of treated wounds: 45 .

\section{Trial site 3: cultivar collection of quinces}

Young (already bearing) trees of several quncie varieties (on quince C rootstock, planted in 1994-1996, spacing 5 by 3 meters) were treated with Relaco after a severe fireblight infection. Number of treated wounds: 55 .

While evaluating the treatments-effect, we measured the diameter of each cuts, and counted the the number of the water shoots formed around the wound and measured their total length (19 October, 2000). After this, we could calculate two indexes to characterize the treatments:

- number of water shoots per $1 \mathrm{~cm}$ of wound circumference, and

- total length of water shoots $(\mathrm{cm})$ per $1 \mathrm{~cm}$ of wound circumference.

Data evaluated with the SPSS/PC+ statistical program package.

\section{Results and discussion}

The Relaco treatments effectively hindered the water shoot formation at all of the trial sites, in spite of the late doing of the treatments. During the season there was hardly any water shoot formation and/or growth around the pruning cuts treated (see table I-3 and Fig. I). The occurrence of water shoots at the untreated wounds could be observed (Fig. 2) as usual: the number of wate shoots per $1 \mathrm{~cm}$ of wound circumference was almost 7 times higher at the untreated pruning cuts of apple trees, and 9 times higher for pear and quince than in the treated trees. The total length of water shoots per $1 \mathrm{~cm}$ of wound circumference was about 16 times higher around the untraeted cuts of apple and pear trees, and 47 times higher for quince trees compared to the treated ones.

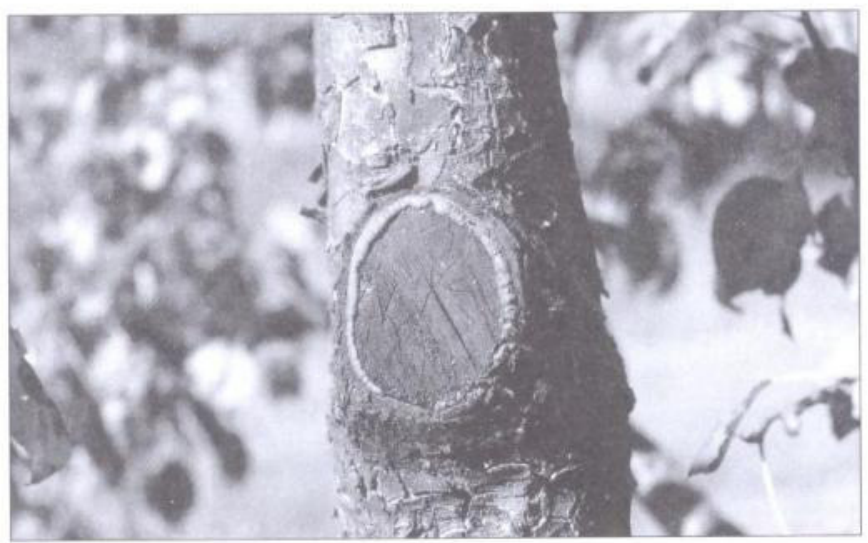

Figure $I$ Pruning wound of a pear tree treated with Relaco

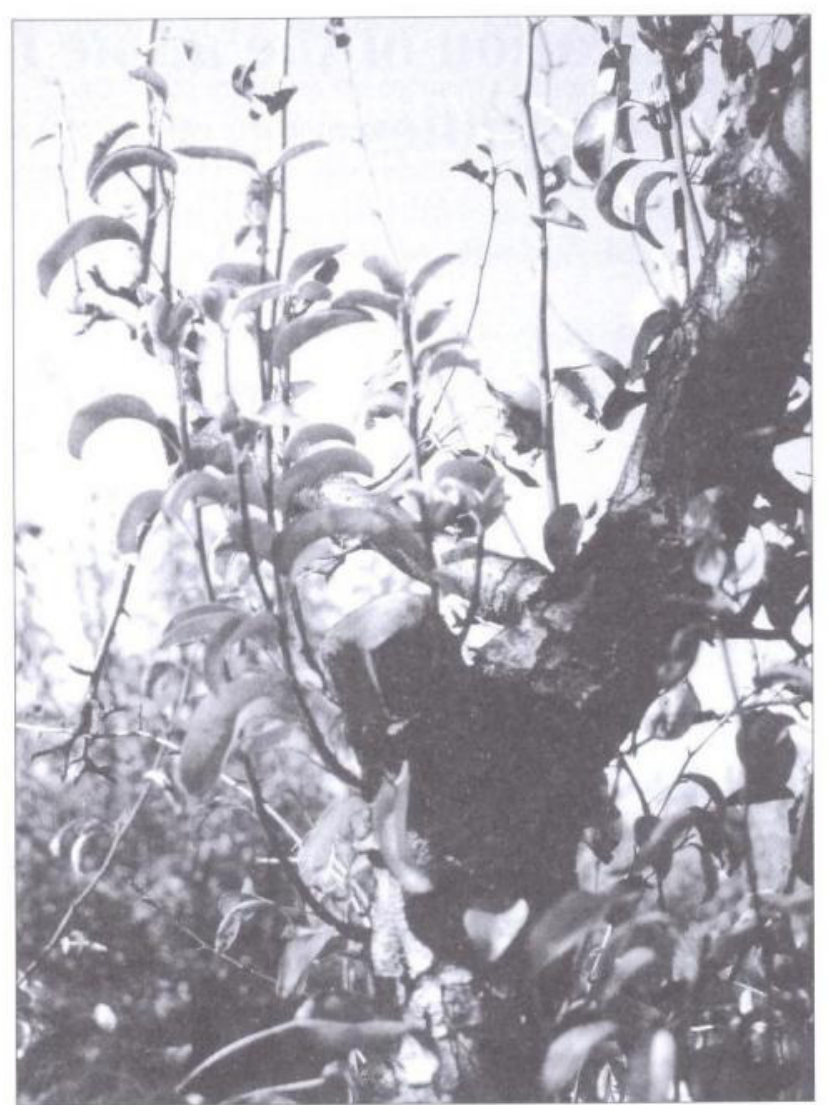

Figure 2 Untreated pruning wound of a pear tree surrounded by water shoots

Table 1 Effect of the Relaco treatment in an apple orchard (Újfehertó, 2000)

\begin{tabular}{|l|c|c|}
\hline \multirow{2}{*}{ Treatments } & Number of water shoots & Total length of water shoots $(\mathrm{cm})$ \\
\cline { 2 - 3 } & \multicolumn{2}{|c|}{ per $1 \mathrm{~cm}$ of wound circumference } \\
\hline Relaco & 0.225 & 11.625 \\
untreated & 0.034 & 0.694 \\
& $* * *$ & $* * *$ \\
\hline
\end{tabular}

$* * *=\mathrm{p}<1 \%$

Table 2 Effect of the Relaco treatment in the pear genebank (Újehértó, 2000)

\begin{tabular}{|c|c|c|}
\hline \multirow{2}{*}{ Treatments } & Number of water shoots & Total length of water shoots $(\mathrm{cm})$ \\
\hline & \multicolumn{2}{|c|}{ per $1 \mathrm{~cm}$ of wound circumference } \\
\hline $\begin{array}{l}\text { Relaco } \\
\text { untreated }\end{array}$ & $\begin{array}{c}0.110 \\
0.012 \\
* * *\end{array}$ & $\begin{array}{c}5.164 \\
0.323 \\
* * * *\end{array}$ \\
\hline
\end{tabular}

Table 3 Effect of the Relaco treatment in the quince cultivar collection (Újfehértó, 2000)

\begin{tabular}{|l|c|c|}
\hline \multirow{2}{*}{ Treatments } & Number of water shoots & Total length of water shoots $(\mathrm{cm})$ \\
\cline { 2 - 3 } & \multicolumn{2}{|c|}{ per $1 \mathrm{~cm}$ of wound circumference } \\
\hline Relaco & 0.155 & 12.667 \\
untreated & 0.017 & 0.268 \\
& ***** & $* * *$ \\
\hline
\end{tabular}

$* * *=\mathrm{p}<1 \%$

\section{References}

Rozsnyai Zs. (2001): Új szer megelổzổ sebkezelésre. Kertészet és Szōlészet. (8):12-14.

Williams, R. R. (1987): Cider and juice apples: growing and processing. University of Bristol Printing Unit. 72-78. 